\title{
Hydrothermal synthesis of new rare earth silicate fluorides: A novel class of polar materials
}

\author{
Colin D. McMillen ${ }^{a}$, Mehtap Emirdag-Eanes ${ }^{b}$, Jared T. Stritzinger ${ }^{a}$, Joseph W. Kolis ${ }^{a, *}$ \\ a Department of Chemistry and Center for Optical Materials Science and Engineering Technologies (COMSET), Clemson University, 485 H.L. Hunter Laboratories, Clemson, \\ SC 29634, USA \\ ${ }^{\mathrm{b}}$ Department of Chemistry, Izmir Institute of Technology, Gulbahce koyu, Urla, Izmir 35430, Turkey
}

\section{A R T I C L E I N F O}

Available online 3 March 2012

Keywords:

Hydrothermal

Silicate fluoride

Single crystal structure

Rare earth silicate

Polar crystals

\begin{abstract}
A B S T R A C T
Polar crystals provide an interesting avenue for materials research both in the structures they form and the properties they possess. This work describes the hydrothermal synthesis and structural characterization of three novel silicate fluorides. Compound (1), $\mathrm{LiY}_{3}\left(\mathrm{SiO}_{4}\right)_{2} \mathrm{~F}_{2}$ crystallizes in space group $\mathrm{C} 2 / c$, with $a=17.651(4) \AA, b=4.8868(10) \AA, c=11.625(2) \AA$ and $\beta=131.13(3)^{\circ} . \mathrm{BaY}_{2}\left(\mathrm{Si}_{2} \mathrm{O}_{7}\right) \mathrm{F}_{2}(2)$ crystallizes in space group $P-1$, with $a=5.1576(10) \AA, \quad b=6.8389(14) \AA, \quad c=11.786(2) \AA, \quad \alpha=93.02(3)^{\circ}$, $\beta=102.05(3)^{\circ}$ and $\gamma=111.55(3)^{\circ}$. Finally, the structure of $\mathrm{Ba}_{2} \mathrm{Y}_{3}\left(\mathrm{SiO}_{4}\right)_{2} \mathrm{~F}_{5}(3)$ was determined in the polar orthorhombic space group Pba2, having unit cell parameters $a=8.8864(18) \AA, b=12.764(3) \AA$ and $c=5.0843(10) \AA$. The structures are compared based on their building blocks and long range polarities. Aligned silicate tetrahedra segregated into a single layer in (3) impart the observed polarity.
\end{abstract}

(c) 2012 Elsevier Inc. All rights reserved.

\section{Introduction and brief review of rare earth silicate fluorides}

Polar compounds are a fascinating canvas for materials research, both in their structural features and their unique physical and optical properties [1]. In particular polar solids have an enormous variety of optoelectronic properties. They can exhibit nonlinear optical effects, ferroelectric properties, domain engineering, surface acoustic waves, quasi-phase matching and numerous other physical manifestations of electro-optic behavior [2]. Of particular interest is the situation whereby a polar acentric structure also contains an ordered rare earth site, especially optically transparent ions like $\mathrm{Y}^{3+}$. This enables the systematic substitution at the site with various laser active ions like $\mathrm{Nd}^{3+}, \mathrm{Yb}^{3+}$ or $\mathrm{Er}^{3+}$. In this case the material can serve the dual function as both the laser material and a second harmonic generator at the same time. Proper orientation of the polar axis helps to generate polarized laser light for subsequent operations like Q-switching. Such materials are called self-frequency doublers and have a number of practical applications [3,4].

In this paper we identify a novel and relatively unexplored class of compounds, namely the metal silicate fluorides, which have a considerable tendency to form polar structures. At the

\footnotetext{
* Corresponding author. Fax: +1 8646566613

E-mail addresses: cmcmill@clemson.edu (C.D. McMillen), mehtapemirdag@iyte.edu.tr (M. Emirdag-Eanes), jstritz@clemson.edu (J.T. Stritzinger), kjoseph@clemson.edu (J.W. Kolis).
}

same time they contain an ordered rare earth ion (preferably yttrium) for systematic substitution, along with a polar axis for additional optical manipulation. We also focus on solids containing one or more alkali or alkaline earth ion, as these provide additional chemical knobs to turn, increasing our chemical and structural flexibility. The mineralogical literature is always a rich initial source of inspiration for functional solids, and the polar materials are no exception [5]. The rare earth element (REE) containing silicate fluorides are an excellent starting point [6]. However, while partial REE substitution can occur over a wide variety of crystallographic sites (especially substituting for $\mathrm{Na}, \mathrm{Ca}$ or other rare earth elements) in natural silicate minerals, the occurrence of well-characterized compounds where a lanthanide is the primary occupant of a given site is confined to a much shorter set of silicate fluoride minerals. Several interesting minerals are based on La or Ce [7-15], and there are a number of synthetic lanthanide silicate fluorides [16-19] and alkali-containing lanthanide silicate fluorides [20-27] reported. Focusing on yttrium-based compounds for reasons just discussed we find nine examples among the naturally-occurring silicate fluorides, and these are summarized in Table 1.

Of these, cappelenite (Ba), hiortdahlite ( $\mathrm{Na}, \mathrm{Ca})$, kapitsaite (Ba), miserite $(\mathrm{K}, \mathrm{Ca})$ and okanoganite $(\mathrm{Na})$ also contain a site where an alkali or alkaline earth metal is the primary occupant. Also, cappelenite and kapitsaite are silico-borates, okanoganite is a silico-borate with phosphorous disorder and kuliokite is an aluminosilicate, so the mineralogical silicate fluorides can be quickly truncated by focusing the search on the alkali- and 
Table 1

Yttrium silicate fluoride minerals.

\begin{tabular}{llll}
\hline Mineral name & General formula & $\begin{array}{l}\text { Space } \\
\text { group }\end{array}$ & Ref. \\
\hline Yftisite & $\mathrm{Y}_{4} \mathrm{Ti}\left(\mathrm{SiO}_{4}\right)_{2} \mathrm{OF}_{6}$ & $\mathrm{Cmcm}$ & {$[28]$} \\
Fluorothalenite & $(\mathrm{Y}, \mathrm{Er})_{3}\left(\mathrm{Si}_{3} \mathrm{O}_{10}\right) \mathrm{F}$ & $P 2_{1} / n$ & {$[29]$} \\
Kuliokite & $\mathrm{Y}_{4} \mathrm{Al}\left(\mathrm{SiO}_{4}\right)_{2}(\mathrm{OH})_{2} \mathrm{~F}_{5}$ & $P 1$ & {$[30]$} \\
Britholite & $(\mathrm{Y}, \mathrm{Ca}, \mathrm{Lu})_{5}\left(\mathrm{SiO}_{3}\right)_{3}(\mathrm{OH}, \mathrm{F})$ & $P 2_{1}$ & {$[31]$} \\
Cappelenite & $\mathrm{Ba}(\mathrm{Y}, \mathrm{REE})_{6}\left(\mathrm{Si}_{3} \mathrm{~B}_{6} \mathrm{O}_{24}\right) \mathrm{F}_{2}$ & $P 3$ & {$[32]$} \\
Hiortdahlite & $(\mathrm{Na}, \mathrm{Ca})_{4}(\mathrm{Ca}, \mathrm{Y})_{8} \mathrm{Zr}_{2}(\mathrm{Y}, \mathrm{Na})_{2}\left(\mathrm{Si}_{2} \mathrm{O}_{7}\right)_{4} \mathrm{O}_{3} \mathrm{~F}_{5}$ & $P-1$ & {$[33]$} \\
Kapitsaite & $(\mathrm{Ba}, \mathrm{K}, \mathrm{Pb})_{4}(\mathrm{Y}, \mathrm{Ca}, \mathrm{Gd})_{2}(\mathrm{Si}, \mathrm{B})_{12} \mathrm{O}_{28} \mathrm{~F}$ & $P-1$ & {$[34]$} \\
Miserite & $(\mathrm{K}, \mathrm{Ca})_{6.4}(\mathrm{Y}, \mathrm{Ce})(\mathrm{Si}, \mathrm{Al})_{8} \mathrm{O}_{22.25}(\mathrm{OH}) \mathrm{F}$ & $P-1$ & {$[35]$} \\
Okanoganite & $(\mathrm{Y}, \mathrm{Ce}, \mathrm{Ca}, \mathrm{Th})_{15}(\mathrm{Fe}, \mathrm{Ti}) \mathrm{Na}(\mathrm{Si}, \mathrm{P})_{7} \mathrm{~B}_{3} \mathrm{O}_{34}(\mathrm{OH})_{4} \mathrm{~F}_{10}$ & $R 3 m$ & {$[36]$} \\
\hline
\end{tabular}

alkaline earth-yttrium silicate fluorides. The collection of yttriumbased silicate fluoride minerals exhibits an interesting structural feature in their propensity to crystallize in polar space groups (four of the nine are polar-cappelenite $(P 3)$, okanoganite $(R 3 m)$, kuliokite $(P 1)$ and britholite $\left.\left(P 2_{1}\right)\right)$.

Based on this tendency it would appear the alkali- and alkaline earth-yttrium silicate fluorides could be potentially rich areas for targeting new polar synthetic materials. These minerals exhibit a variety of means by which polarity can be achieved. For example, the polarities of cappelenite and okanoganite are most apparent by alignment of borate and silicate tetrahedra (where the direction of specific B-O or Si-O bonds collectively work in concert to impart polarity), respectively, in sheets or layers in the structure. Britholite is polar due to a shortening of certain rare earth oxide bonds which breaks the mirror symmetry of the apatite structure. Even with these interesting structural tendencies, there seems to be a somewhat limited precedent for synthetic yttrium silicate fluorides, with the only examples being the alkali metal-based compounds $\mathrm{Cs}_{2} \mathrm{Y}\left(\mathrm{Si}_{4} \mathrm{O}_{10}\right) \mathrm{F}$ [37] and $\mathrm{Na}_{5} \mathrm{Y}_{4}\left(\mathrm{SiO}_{4}\right)_{4} \mathrm{~F}$ [38]. Synthetic alkaline earth-yttrium silicate fluorides appear completely neglected, and one must begin to consider other rare earth ions as in $\mathrm{Ba}_{2} \mathrm{Ce}_{3}\left(\mathrm{SiO}_{4}\right)_{3} \mathrm{~F}$ [39] and $\mathrm{La}_{6} \mathrm{Ba}_{4}$ $\left(\mathrm{SiO}_{4}\right)_{6} \mathrm{~F}_{2}[40]$ in order to gain a foothold in this synthetic phase space. One possible reason for the lack of progress in the synthetic metal silicate fluoride systems is the tendency of silicates and silicate fluorides to form viscous liquids and glasses from their melts. Amphoteric oxides, however, tend to form high quality single crystals in hydrothermal fluids, so we felt confident that this promising class of compounds would lend themselves to this plan of attack.

The interplay of $\mathrm{OH}^{-}$and $\mathrm{F}^{-}$in the structures of many naturally occurring silicates and silicate fluoride species hints at their hydrothermal origins, and we have recently demonstrated that many fluoride-containing species resist hydrolysis during hydrothermal synthesis [41-45]. In particular, we recently isolated crystals of a new class of alkaline earth borate fluorides $M_{3} \mathrm{~B}_{6} \mathrm{O}_{11} \mathrm{~F}_{2}(M=\mathrm{Sr}, \mathrm{Ba})$ which crystallize in the polar space group $P 2_{1}$ [46]. These structures exhibit a directed polarity based on the alignment of $\left[\mathrm{BO}_{3}\right]$ triangles in the unit cell. Like $\mathrm{B}_{2} \mathrm{O}_{3}, \mathrm{SiO}_{2}$ is an amphoteric oxide, so we have extended our hydrothermal exploration of phase space to seek novel silico-borates and silicate fluorides. In this paper we introduce three new members of this latter class of compounds, namely $\mathrm{LiY}_{3}(-$ $\left.\mathrm{SiO}_{4}\right)_{2} \mathrm{~F}_{2}(\mathbf{1}), \mathrm{BaY}_{2}\left(\mathrm{Si}_{2} \mathrm{O}_{7}\right) \mathrm{F}_{2}(\mathbf{2})$ and $\mathrm{Ba}_{2} \mathrm{Y}_{3}\left(\mathrm{SiO}_{4}\right)_{2} \mathrm{~F}_{5}$ (3). The structures are contrasted with one another, particularly in the aspects which affect (3) crystallizing in a polar space group.

\section{Materials and methods}

Single crystals of the title compounds were synthesized through a general two-step process of melt growth of starting materials followed by hydrothermal treatment. Starting materials were prepared from melts in platinum crucibles performed in air at $1000{ }^{\circ} \mathrm{C}$ for $24 \mathrm{~h}$. For $\mathrm{LiY}_{3}\left(\mathrm{SiO}_{4}\right)_{2} \mathrm{~F}_{2}(\mathbf{1})$, the precursor powders were: $0.26 \mathrm{~g}$ (10 mmol) LiF, $1.1 \mathrm{~g}(7.5 \mathrm{mmol}) \mathrm{YF}_{3}, \quad 0.30 \mathrm{~g}$ $(5.0 \mathrm{mmol}) \mathrm{SiO}_{2}$ and $0.092 \mathrm{~g}(2.5 \mathrm{mmol}) \mathrm{NH}_{4} \mathrm{~F}$. For BaY $\left.\mathrm{Bai}_{2} \mathrm{O}_{7}\right) \mathrm{F}_{2}$ (2), the precursor powders were: $0.88 \mathrm{~g}$ (5.0 mmol) $\mathrm{BaF}_{2}, 1.1 \mathrm{~g}$ (7.5 mmol) $\mathrm{YF}_{3}$ and $0.30 \mathrm{~g}(5.0 \mathrm{mmol}) \mathrm{SiO}_{2}$. For $\mathrm{Ba}_{2} \mathrm{Y}_{3}\left(\mathrm{SiO}_{4}\right)_{2} \mathrm{~F}_{5}(3)$, the precursor powders were: $0.88 \mathrm{~g}(5.0 \mathrm{mmol}) \mathrm{BaF}_{2}, 1.45 \mathrm{~g}$ (10 mmol) $\mathrm{YF}_{3}$ and $0.06 \mathrm{~g}(1 \mathrm{mmol}) \mathrm{SiO}_{2}$. The resulting powders in each case were then loaded $(0.11 \mathrm{~g})$ into individual silver ampoules along with $0.4 \mathrm{~mL}$ of an aqueous mineralizer solution. Mineralizers used were $2 \mathrm{M} \mathrm{KF}$ in the synthesis of $(\mathbf{1})$ and (2), and $2 \mathrm{M} \mathrm{KHF}_{2}$ was used to synthesize (3).The ampoules were weldsealed and placed in an autoclave with excess water for counter pressure, and the autoclave was heated to $575{ }^{\circ} \mathrm{C}$ for 4 days, autogenously producing a pressure of $20 \mathrm{kpsi}$. The autoclave was then cooled to room temperature over $12 \mathrm{~h}$ and the crystals were harvested from the ampoules. Crystals of (1) formed as colorless diamond-shaped plates, while crystals of (2) and (3) formed as colorless rods. We note that while these products have not yet been synthesized in a phase pure yield (they are typically contaminated with binary fluoride crystals such as $\mathrm{LiF}, \mathrm{BaF}_{2}$ and $\mathrm{YF}_{3}$ ), the variety of silicate fluoride products obtained in these preliminary reactions seem to suggest a rich hydrothermal phase space can be explored by varying the metal and silicate ratios in the reactions.

Single crystal $x$-ray diffraction of the resulting crystals was performed using a Rigaku AFC8S diffractometer equipped with $\operatorname{MoK} \alpha(\lambda=0.71073 \AA)$ radiation and a Mercury CCD area detector. Data collection and processing, including corrections for absorption and Lorentz and polarization effects was performed using the CrystalClear software package [47]. Candidate space groups were identified based on the systematic absences of the data. The structures were solved by direct methods and refined by fullmatrix least squares on $F^{2}$ using the SHELXTL software package [48]. All atoms were refined anisotropically in all structures. Elemental analysis by EDX was performed to confirm the presence of fluorine in each structure and to verify the approximate ratios of $\mathrm{Ba}: \mathrm{Y}$ in compounds (2) and (3). Within the sensitivity of EDX we note good agreement in the compositions of the solved structures and the elemental analysis data (supporting information Table S1). In all cases, $\mathrm{F}$ atoms were crystallographically distinguished from $\mathrm{O}$ atoms by bond valence analyses of the atoms in question.

The structure of (1) was determined in the monoclinic space group $C 2 / c$, with $a=17.651(4) \AA, b=4.8868(10) \AA, c=11.625(2) \AA$ and $\beta=131.13(3)^{\circ}$. Consecutive refinements resulted in a final $R_{1}$ value of 0.0407 based on the observed data. The structure of $(2)$ was solved to a final $R_{1}$ value of 0.0292 in space group $P-1$, with $a=5.1576(10) \AA, \quad b=6.8389(14) \AA, \quad c=11.786(2) \AA, \quad \alpha=93.02(3)^{\circ}$, $\beta=102.05(3)^{\circ}$ and $\gamma=111.55(3)^{\circ}$. The structure of $(3)$ was solved in the polar, acentric orthorhombic space group $P b a 2$, having unit cell parameters $a=8.8864(18) \AA, b=12.764(3) \AA$ and $c=5.0843(10) \AA$. A final $R_{1}$ value of 0.0273 was obtained after consecutive refinements and a Flack parameter of -0.027 also statistically suggested the acentricity and absolute structure (polarity). A summary of the crystallographic data for these structure determinations is given in Table 2.

\section{Results and discussion}

\subsection{Crystal structure of $\mathrm{LiY}_{3}\left(\mathrm{SiO}_{4}\right)_{2} \mathrm{~F}_{2}(\mathbf{1})$}

To our knowledge this is the first reported single crystal structure of a lithium ytrrium silicate fluoride. The structure of (1) can be described as a framework of $\left[\mathrm{LiO}_{6}\right],\left[\mathrm{YO}_{6} \mathrm{~F}_{2}\right]$ and $\left[\mathrm{YO}_{6} \mathrm{~F}\right]$ polyhedra with small gaps that are occupied by $\left[\mathrm{SiO}_{4}\right]$ tetrahedra 
Table 2

Crystallographic data of novel silicate fluorides.

\begin{tabular}{|c|c|c|c|}
\hline & (1) & (2) & (3) \\
\hline Empirical formula & $\mathrm{LiY}_{3}\left(\mathrm{SiO}_{4}\right)_{2} \mathrm{~F}_{2}$ & $\mathrm{BaY}_{2}\left(\mathbf{S i}_{2} \mathbf{O}_{7}\right) \mathbf{F}_{2}$ & $\mathrm{Ba}_{2} \mathbf{Y}_{3}\left(\mathrm{SiO}_{4}\right)_{2} \mathbf{F}_{5}$ \\
\hline Formula weight & 495.85 & 521.34 & 820.59 \\
\hline Space group & $C 2 / c($ no. 15$)$ & $P-1($ no. 2$)$ & Pba2 (no. 32) \\
\hline$a(\AA)$ & $17.651(4)$ & $5.1576(10)$ & $8.8864(18)$ \\
\hline$b(\AA)$ & $4.8868(10)$ & $6.8389(14)$ & $12.764(3)$ \\
\hline$c(\AA)$ & $11.625(2)$ & $11.786(2)$ & $5.0843(10)$ \\
\hline$\alpha$ (deg.) & 90 & $93.02(3)$ & 90 \\
\hline$\beta$ (deg.) & $131.13(3)$ & $102.05(3)$ & 90 \\
\hline$\gamma$ (deg.) & 90 & $111.55(3)$ & 90 \\
\hline$V\left(\AA^{3}\right)$ & $755.2(3)$ & $374.30(12)$ & $576.7(2)$ \\
\hline$Z$ & 4 & 2 & 2 \\
\hline$D_{\text {calc }}\left(\mathrm{Mg} / \mathrm{m}^{3}\right)$ & 4.361 & 4.626 & 4.726 \\
\hline Parameters & 76 & 127 & 93 \\
\hline$\mu\left(\mathrm{mm}^{-1}\right)$ & 23.243 & 20.946 & 21.966 \\
\hline$\theta$ range (deg.) & $3.06-25.02$ & $3.24-26.68$ & $2.79-26.34$ \\
\hline \multicolumn{4}{|l|}{ Reflections } \\
\hline Collected & 3045 & 3688 & 5016 \\
\hline Independent & 658 & 1565 & 1159 \\
\hline Observed $[I \geq 2 \sigma(I)]$ & 597 & 1328 & 1123 \\
\hline$R$ (int) & 0.0819 & 0.0303 & 0.0510 \\
\hline \multicolumn{4}{|l|}{ Final $R$ (obs. data) ${ }^{\mathrm{a}}$} \\
\hline$R_{1}$ & 0.0407 & 0.0292 & 0.0273 \\
\hline $\mathrm{w} R_{2}$ & 0.1067 & 0.0542 & 0.0601 \\
\hline \multicolumn{4}{|l|}{ Final $R$ (all data) } \\
\hline$R_{1}$ & 0.0446 & 0.0374 & 0.0286 \\
\hline$w R_{2}$ & 0.1105 & 0.0575 & 0.0606 \\
\hline Goodness of fit on $F^{2}$ & 1.121 & 1.101 & 1.123 \\
\hline Flack parameter & - & - & $-0.027(11)$ \\
\hline Largest diff. peak $\left(\mathrm{e} / \AA^{3}\right)$ & 1.831 & 1.380 & 1.109 \\
\hline Largest diff. hole $\left(\mathrm{e} / \AA^{3}\right)$ & -1.575 & -0.986 & -0.962 \\
\hline
\end{tabular}

${ }^{\mathrm{a}} R_{1}=\left[\sum\left\|F_{\mathrm{o}}|-| F_{\mathrm{c}}\right\|\right] / \sum\left|F_{\mathrm{o}}\right| ; \mathrm{w} R_{2}=\left\{\left[\sum w\left[\left(F_{\mathrm{o}}\right)^{2}-\left(F_{\mathrm{c}}\right)^{2}\right]^{2}\right]\right\}^{1 / 2}$.

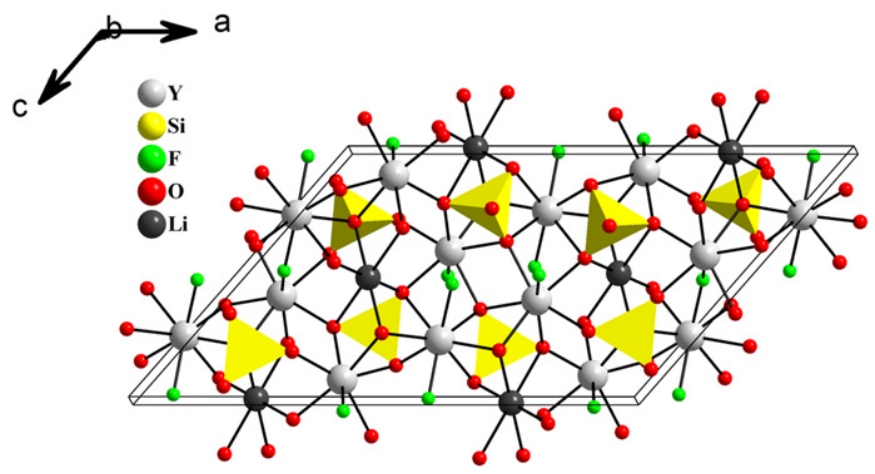

Fig. 1. Structure of $\mathrm{LiY}_{3}\left(\mathrm{SiO}_{4}\right)_{2} \mathrm{~F}_{2}$ viewed off the $b$-axis.

(Fig. 1). Individually, the $\left[\mathrm{LiO}_{6}\right]$ polyhedra are distorted octahedra having four equatorial $\mathrm{Li}-\mathrm{O}$ bonds of the typical bond length of 2.132(5) and 2.154(5) (Table 3) and two extremely long interactions $(2.773(9) \AA)$ at the axial positions. While evaluation of the bond distances appears to support a tetrahedral configuration, inspection of the $\mathrm{O}-\mathrm{Li}-\mathrm{O}$ angles strongly supports the octahedral configuration, and the long bonds should be considered despite their minimal contribution to the valence of Li. Independently, the bonding to both oxide and fluoride anions results in locally polar individual environments about both the seven- and eight-coordinate $\mathrm{Y}$ atoms, as the fluorine atoms are confined to the same side (with respect to the $b$-axis) of the eight-coordinate square antiprism. However, this local polarity is broken in the longer range space symmetry of the unit cell. We note that in both $Y$ environments the fluoride bonds are noticeably shorter than the oxide bonds and only participate in bridging $\mathrm{Y} 1$ and $\mathrm{Y} 2$ by corner sharing of F1. Both edge and corner sharing interactions through oxygen atoms further connect the yttrium and lithium atoms to form that framework.

The silicate tetrahedra deserve some comment, particularly in the directionality of the $\mathrm{Si}-\mathrm{O}$ vectors when viewed along their three-fold axes (though not a true three-fold axis given the distorted nature of the $\mathrm{Si}-\mathrm{O}$ tetrahedra). Compound (1) possesses two different layers of $\left[\mathrm{SiO}_{4}\right]$ tetrahedra occurring along the $c$-axis of the unit cell, most distinguishable in Fig. 1 by the position of their apical oxygen atoms along the $b$-axis. However, the layers are related to one another by inversion symmetry again destroying any long range polarity in the structure. The tetrahedra themselves are slightly distorted in their angular arrangement with bond angles ranging from $101.9(3)^{\circ}$ to $116.2(3)^{\circ}$. Each oxygen atom of the silicate group acts as a vertex for three additional atoms such that the $\left[\mathrm{SiO}_{4}\right]$ tetrahedron is edge sharing with each of the $\mathrm{Li}$ and $\mathrm{Y}$ polyhedra around the base of the tetrahedron (again, viewing down the $b$-axis as in Fig. 1) and corner sharing with the Li and Y polyhedra through the apical oxygen atom. Thus the edge sharing seen in this structure type provides a rather snug fit for the silicate group (though it should be noted that edge sharing with $\mathrm{Li}$ is partially achieved through one of the longer $\mathrm{Li}-\mathrm{O}$ interactions).

\subsection{Crystal structure of $\mathrm{BaY}_{2}\left(\mathrm{Si}_{2} \mathrm{O}_{7}\right) \mathrm{F}_{2}$ (2)}

Compounds (2) and (3) represent to our knowledge the first barium yttrium silicate fluorides to be structurally characterized. We do note that cappelenite and kapitsaite mentioned earlier are based on both Ba and Y, but the presence of borate building blocks in those structures distinguish them as a different class of materials. In contrast to (1) the structure of $(\mathbf{2})$ features pyrosilicate $\left(\left[\mathrm{Si}_{2} \mathrm{O}_{7}\right]^{6-}\right)$ anionic building blocks which exhibit slight bond distance and angle distortions. Like (1) the pyrosilicates do not exhibit alignment over the entirety of the unit cell, and the inversion center is clearly visible in Fig. 2. Four yttrium (two unique) and two barium (one unique) atoms (as $\left[\mathrm{YO}_{7}\right],\left[\mathrm{YO}_{4} \mathrm{~F}_{4}\right]$ and $\left[\mathrm{BaO}_{7} \mathrm{~F}_{2}\right]$ polyhedra) edge share to form a cluster about the inversion center in the unit cell. Corner sharing of $\mathrm{O} 5$ by Ba 1 and Y2 provides additional reinforcement within the cluster. The clusters extend to neighboring unit cells through $\mathrm{Y}-\mathrm{O}-\mathrm{Y}$ and $\mathrm{Ba}-\mathrm{O}-\mathrm{Y}$ interactions, forming a long range framework. Clusters also connect through $\mathrm{Y}-\mathrm{F}-\mathrm{Y}$ and $\mathrm{Ba}-\mathrm{F}-\mathrm{Y}$ bridging, but since all the fluorine atoms are confined to the middle of the unit cell (with respect to the $c$-axis), these connections contribute primarily to extending the structure only along the $a$ and $b$ axes. The pyrosilicate group extends outward from the cluster of metal atoms, also providing connectivity to the rings of neighboring unit cells. Like the structure of $(\mathbf{1})$, the $\left[\mathrm{Si}_{2} \mathrm{O}_{7}\right]$ groups can also be viewed as filling the small voids in the metal oxyfluoride framework. As is usually observed, the bridging Si1-O1-Si2 bonds in the pyrosilicate group are slightly elongated at 1.673(5) A for Si1$\mathrm{O} 1$ and $1.693(5) \AA$ for Si2-O1. Terminal $\mathrm{Si}-\mathrm{O}$ bonds range from $1.601(4) \AA$ to $1.643(4) \AA$. Bond angles ranging from $102.1(2)^{\circ}$ to $117.4(2)^{\circ}$ again indicate a slight distortion of the tetrahedra. In general, the eight-coordinate $\mathrm{Y} 1$ polyhedron is a square antiprism, though the low symmetry of the crystal system allows for a good bit of distortion. Its arrangement is interesting, however, with one "square face" of the antiprism consisting of three fluorine atoms and one oxygen, while the other consists of one fluorine and three oxygen atoms. The $\left[\mathrm{BaO}_{7} \mathrm{~F}_{2}\right]$ polyhedron similarly pairs its fluorine atoms near one another in its coordination sphere. 
Table 3

Selected bond distances $(\AA)$ and angles (deg.).

\begin{tabular}{|c|c|c|c|c|c|}
\hline $\mathrm{LiY}_{3}\left(\mathrm{SiO}_{4}\right)_{2} \mathrm{~F}_{2}(\mathbf{1})$ & & $\mathrm{BaY}_{2}\left(\mathrm{Si}_{2} \mathbf{O}_{7}\right) \mathbf{F}_{2}(2)$ & & $\mathrm{Ba}_{2} \mathrm{Y}_{3}\left(\mathrm{SiO}_{4}\right)_{2} \mathrm{~F}_{5}$ & \\
\hline Distances & & Distances & & Distances & \\
\hline $\mathrm{Y} 1-\mathrm{F} 1$ & $2.220(4)(\times 2)$ & $\mathrm{Y} 1-04$ & $2.244(4)$ & Y1-01 & $2.314(6)(\times 2)$ \\
\hline $\mathrm{Y} 1-\mathrm{O} 2$ & $2.292(4)(\times 2)$ & $\mathrm{Y} 1-03$ & $2.249(4)$ & $\mathrm{Y} 1-\mathrm{O} 2$ & $2.381(6)(\times 2)$ \\
\hline $\mathrm{Y} 1-01$ & $2.354(5)(\times 2)$ & $\mathrm{Y} 1-\mathrm{O} 2$ & $2.263(4)$ & Y1-F1 & $2.406(5)(\times 2)$ \\
\hline $\mathrm{Y} 1-\mathrm{O} 4$ & $2.471(5)(\times 2)$ & $\mathrm{Y} 1-07$ & $2.341(4)$ & $\mathrm{Y} 1-03$ & $2.414(6)(\times 2)$ \\
\hline $\mathrm{Y} 2-\mathrm{F} 1$ & $2.219(4)$ & Y1-05 & $2.351(4)$ & Y2-O4 & $2.228(5)$ \\
\hline Y2-03 & $2.263(5)$ & $\mathrm{Y} 1-\mathrm{O} 2$ & $2.385(4)$ & Y2-F2 & $2.243(5)$ \\
\hline Y2-04 & $2.292(5)$ & $\mathrm{Y} 1-01$ & $2.624(5)$ & $\mathrm{Y} 2-\mathrm{O} 2$ & $2.254(6)$ \\
\hline Y2-O3 & $2.317(5)$ & Y2-F1 & $2.197(4)$ & Y2-O3 & $2.306(6)$ \\
\hline $\mathrm{Y} 2-\mathrm{O} 2$ & $2.338(6)$ & $\mathrm{Y} 2-\mathrm{F} 2$ & $2.263(4)$ & $\mathrm{Y} 2-\mathrm{F} 3$ & $2.315(6)$ \\
\hline $\mathrm{Y} 2-\mathrm{O} 2$ & $2.419(5)$ & Y2-06 & $2.302(4)$ & $\mathrm{Y} 2-\mathrm{F} 1$ & $2.354(5)$ \\
\hline \multirow[t]{2}{*}{$\mathrm{Y} 2-\mathrm{O} 1$} & $2.454(4)$ & Y2-F2 & $2.349(4)$ & $\mathrm{Y} 2-\mathrm{F} 1$ & $2.360(5)$ \\
\hline & & Y2-07 & $2.354(4)$ & & \\
\hline Li1-O4 & $2.132(5)(\times 2)$ & Y2-05 & $2.424(4)$ & $\mathrm{Ba} 1-\mathrm{F} 1$ & $2.592(5)$ \\
\hline Li1-01 & $2.154(5)(\times 2)$ & Y2-06 & $2.431(5)$ & $\mathrm{Ba} 1-03$ & $2.690(6)$ \\
\hline \multirow[t]{2}{*}{ Li1-O3 } & $2.773(9)(\times 2)$ & Y2-F1 & $2.456(4)$ & $\mathrm{Ba} 1-\mathrm{O} 2$ & $2.705(6)$ \\
\hline & & & & $\mathrm{Ba} 1-\mathrm{O} 4$ & $2.813(6)$ \\
\hline Si1-01 & $1.624(5)$ & Ba1-F1 & $2.616(4)$ & $\mathrm{Ba} 1-\mathrm{O} 1$ & $2.845(6)$ \\
\hline Si1-O3 & $1.630(5)$ & Ba1-O5 & $2.694(4)$ & $\mathrm{Ba} 1-\mathrm{F} 2$ & $2.932(5)$ \\
\hline Si1-04 & $1.634(5)$ & $\mathrm{Ba} 1-\mathrm{F} 2$ & $2.718(4)$ & Ba1-O4 & $2.977(6)$ \\
\hline \multirow[t]{2}{*}{$\mathrm{Si} 1-\mathrm{O} 2$} & $1.664(6)$ & $\mathrm{Ba} 1-04$ & $2.763(4)$ & $\mathrm{Ba} 1-\mathrm{O} 1$ & $3.016(6)$ \\
\hline & & $\mathrm{Ba} 1-03$ & $2.798(5)$ & Ba1-F3 & $3.101(2)$ \\
\hline Angles & & Ba1-06 & $2.834(4)$ & & \\
\hline O4-Li1-01 & $92.7(2)$ & Ba1-O1 & $2.945(4)$ & Si1-01 & $1.613(6)$ \\
\hline O4-Li1-01 & $87.3(2)$ & Ba1-04 & $2.986(5)$ & $\mathrm{Si} 1-\mathrm{O} 4$ & $1.619(6)$ \\
\hline O4-Li1-O3 & $115.2(2)$ & $\mathrm{Ba} 1-\mathrm{O} 2$ & $3.031(4)$ & Si1-O3 & $1.631(6)$ \\
\hline O4-Li1-O3 & $64.8(2)$ & & & $\mathrm{Si} 1-\mathrm{O} 2$ & $1.648(6)$ \\
\hline O1-Li1-O3 & $102.7(2)$ & Si1-07 & $1.604(4)$ & & \\
\hline \multirow[t]{2}{*}{ O1-Li1-O3 } & $79.3(2)$ & Si1-06 & $1.615(4)$ & Angles & \\
\hline & & Si1-O5 & $1.626(5)$ & O1-Si1-04 & $114.6(3)$ \\
\hline O1-Si1-O3 & $114.5(3)$ & Si1-01 & $1.674(5)$ & O1-Si1-O3 & $111.7(3)$ \\
\hline O1-Si1-O4 & $116.2(2)$ & $\mathrm{Si} 2-\mathrm{O} 3$ & $1.601(4)$ & O1-Si1-O2 & $113.0(3)$ \\
\hline O1-Si1-O2 & $110.5(3)$ & $\mathrm{Si} 2-\mathrm{O} 4$ & $1.619(4)$ & O3-Si1-O2 & $101.8(3)$ \\
\hline \multirow[t]{11}{*}{ O4-Si1-O2 } & $101.3(3)$ & $\mathrm{Si} 2-\mathrm{O} 2$ & $1.643(4)$ & & \\
\hline & & Si2-01 & $1.693(5)$ & & \\
\hline & & Angles & & & \\
\hline & & O7-Si1-06 & $117.4(2)$ & & \\
\hline & & O7-Si1-O5 & $115.4(2)$ & & \\
\hline & & O7-Si1-01 & $110.2(2)$ & & \\
\hline & & O5-Si1-O1 & $102.1(2)$ & & \\
\hline & & $\mathrm{O} 3-\mathrm{Si} 2-\mathrm{O} 4$ & $115.7(2)$ & & \\
\hline & & $\mathrm{O} 3-\mathrm{Si} 2-\mathrm{O} 2$ & $111.0(2)$ & & \\
\hline & & $\mathrm{O} 3-\mathrm{Si} 2-\mathrm{O} 1$ & $108.9(2)$ & & \\
\hline & & O4-Si2-01 & $103.3(2)$ & & \\
\hline
\end{tabular}



Fig. 2. Extended unit cell of $\mathrm{BaY}_{2}\left(\mathrm{Si}_{2} \mathrm{O}_{7}\right) \mathrm{F}_{2}$ viewed off the $a$-axis.

\subsection{Polar crystal structure of $\mathrm{Ba}_{2} \mathrm{Y}_{3}\left(\mathrm{SiO}_{4}\right)_{2} \mathrm{~F}_{5}$ (3)}

The most interesting structure of these novel compounds is that of (3) due to its polar nature. Like (2), this structure is based on one unique Ba atom and two unique $\mathrm{Y}$ atoms which form a framework that accommodates the silicate polyhedra, which in the case of (3) is an isolated, slightly distorted tetrahedron. Barium is again ninecoordinate, but this time it is a $\left[\mathrm{BaO}_{6} \mathrm{~F}_{3}\right]$ polyhedron. There is one rather long Ba1-F3 interaction of 3.101(2) $\AA$ in this polyhedron, but as this $\mathrm{F}$ atom is four-coordinate (two bonds to Ba1 and two bonds to Y2) the bond valence of F3 remains satisfied. The other fluorine atoms are both three-coordinate (with two bonds to yttrium atoms and one bond to barium) and exhibit the typical bond distances. The unique yttrium atoms are seven-coordinate as $\left[\mathrm{YO}_{3} \mathrm{~F}_{4}\right]$ (distorted pentagonal bipyramid) and eight-coordinate as $\left[\mathrm{YO}_{6} \mathrm{~F}_{2}\right]$ (square antiprism). The angular distortion in the pentagonal bipyramid results in non-collinear $\left(150.8(2)^{\circ}\right)$ axial $\mathrm{F}$ atoms. Furthermore, the fluorine and oxygen atoms are segregated on opposite sides of the polyhedron making this a rather unusual environment. These are shown as the yttrium polyhedra in Fig. 3. In the $\left[\mathrm{YO}_{6} \mathrm{~F}_{2}\right]$ square antiprism the fluorine atoms are both on the same "square face" of the antiprism along the $c$-axis, similar to the arrangement in (1). However, this time that arrangement is maintained throughout the unit cell and contributes to the polarity of the structure.

The $\left[\mathrm{SiO}_{4}\right]$ tetrahedra are all corner sharing with both types of yttrium polyhedra and also corner sharing with the barium 




Fig. 3. Unit cell of $\mathrm{Ba}_{2} \mathrm{Y}_{3}\left(\mathrm{SiO}_{4}\right)_{2} \mathrm{~F}_{5}$ viewed off the $c$-axis. Bonds to Ba are omitted for clarity and pentagonal bipyramidal $\mathrm{Y} 2$ atoms are shown as gray polyhedra.

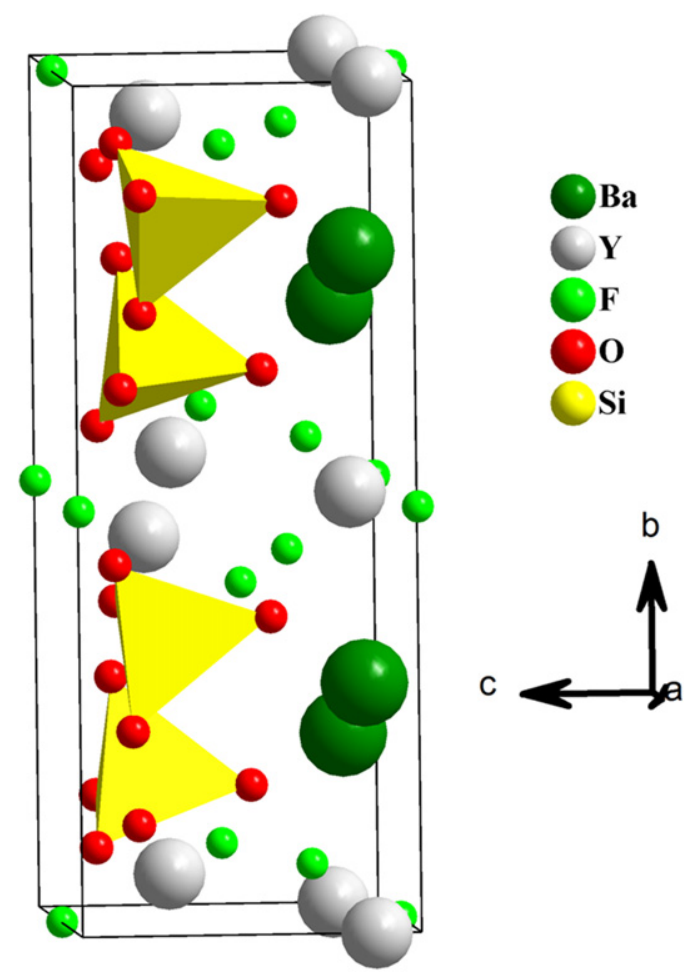

Fig. 4. Layered structure of (3) indicating polar segregation of unique metal and silicate environments.

polyhedra. The Si-O bond distance is fairly regular (1.613(6)$1.648(6) \AA)$ and the $\mathrm{O}-\mathrm{Si}-\mathrm{O}$ angular distortion (101.8(3)$\left.114.6(3)^{\circ}\right)$ is similar to that observed in (1) and (2). The polarity of the silicate groups with respect to their apical oxygen atoms along the tetrahedra's three-fold axis is apparent in Fig. 3. Unlike compounds (1) and (2) the local polarity is maintained throughout the unit cell and is a distinct polar feature to the structure.
That polarity is also apparent in Fig. 4, which also shows an additional polar aspect of this structure in two distinct layers. The layered nature of the structure along the $c$-axis is evident, where there are two clearly different layers: one containing Y1 and Ba1 and the other containing Y2 and Si1. Thus the Si1-O1 bonds of the silicate tetrahedra are all aligned in their direction along the $c$ axis and they are all segregated to one side of the unit cell (likewise, the yttrium and barium atoms are also segregated). This feature of a polar layer of silicate tetrahedra that corner share with metal polyhedra is somewhat reminiscent of what imparts polarity in okanoganite [37] where the central layer of this threelayer structure contains aligned isolated silicate tetrahedra that also corner share with neighboring metal polyhedra. Similarly, cappelenite features layers of silicoborate sheets with tetrahedral borate groups whose apical oxygens all point in one direction [32]. Thus the current structure has some features that mimic a mineralogical blueprint for polar crystals.

\section{Conclusions}

Naturally occurring yttrium silicate fluorides seem to possess a unique tendency to crystallize in polar space groups and may offer a pathway for the synthetic chemist to pursue such interesting compounds. The structures described in this study offer an initial foray into the hydrothermal preparation and characterization of an underexplored area of phase space, namely synthetic alkali and alkaline earth yttrium silicate fluorides. To our knowledge these are the first examples of materials in those classes of compounds to be characterized by single crystal $\mathrm{x}$-ray diffraction. Interestingly, one of the three novel species synthesized, $\mathrm{Ba}_{2} \mathrm{Y}_{3}$ $\left(\mathrm{SiO}_{4}\right)_{2} \mathrm{~F}_{5}$, crystallizes in the acentric, polar space group Pba2. In this structure, aligned $\mathrm{Si}-\mathrm{O}$ bonds of silicate tetrahedra in a segregated layer arrangement provide the primary polar feature. Unusual alkaline earth and rare earth metal building blocks with polar features may also offer some contribution to the overall polarity of that structure. The other two centrosymmetric species, $\mathrm{LiY}_{3}\left(\mathrm{SiO}_{4}\right)_{2} \mathrm{~F}_{2}$ and $\mathrm{BaY}_{2}\left(\mathrm{Si}_{2} \mathrm{O}_{7}\right) \mathrm{F}_{2}$ do not feature a comparable layered arrangement, and the orientations of the individual silicate groups are inverted over the long range structures. So while we have not quite achieved the same success ratio in this study (33\%) as the mineralogical world (44\%) in finding polar yttrium silicate fluorides we feel this initial work may open the silicate fluoride phase space to further study. This work does offer a new synthetic example of how aligned $\mathrm{Si}-\mathrm{O}$ vectors in silicate tetrahedra in a simple two-layered structure can be useful in directing polar structures. The wide variation in potential synthetic conditions, and the significant chemical flexibility imparted by the presence of alkali and alkaline earth ions, suggests that an enormous class of new materials awaits, many of which will undoubtedly be polar. Further, the presence of the rare earth site will allow for substitution by laser active ions. These investigations are currently underway.

\section{Acknowledgments}

The authors are grateful for support of this project by The National Science Foundation (DMR-0907395).

\section{Appendix A. Supporting information}

Supplementary data associated with this article can be found in the online version at doi:10.1016/j.jssc.2012.02.057. 


\section{References}

[1] P.S. Halasyamani, K.R. Poeppelmeier, Chem. Mater. 10 (1998) 2753-2769.

[2] S.C. Abrahams, Acta Crystallogr. A50 (1994) 658-685.

[3] G. Aka, A. Brenier, Opt. Mater. 22 (2003) 89-94.

[4] J. Eichenholz, B.H.T. Chai, Q. Ye, M. Richardson, D.A. Hammons, US Patent 6,185,236 B1, February 2001.

[5] R.E. Newnham, Am. Mineral. 59 (1974) 906-918.

[6] J.W. Anthony, R.A. Bideaux, K.W. Bladh, M.C. Nichols, Handbook of Mineralogy: vol. II-Silica, Silicates, Mineral Data Publishing, Tucson, AZ, 1995.

[7] N. Kalsbeek, S. Larsen, J.G. Ronsbo, Z. Kristallogr. 191 (1990) 249-263.

[8] R. Oberti, L. Ottolini, F. Camara, G. della Ventura, Am. Mineral. 84 (1999) 913-921.

[9] J.D. Grice, R. Rowe, G. Poirier, A. Pratt, J. Francis, Can. Mineral. 47 (2009) 193-204.

[10] M. Boiocchi, A. Callegari, L. Ottolini, Am. Mineral. 91 (2006) 1170-1177.

[11] D. Holtstam, U. Kolitsch, U.B. Anderson, Eur. J. Mineral. 17 (2005) 129-141.

[12] F. Mazzi, L. Ungaretti, A. dal Negro, O.V. Petersen, J.G. Ronsbo, Am. Mineral. 64 (1979) 202-210.

[13] P. Ballirano, A. Callegari, F. Caucia, A. Maras, F. Mazzi, L. Ungaretti, Am. Mineral. 87 (2002) 1139-1143.

[14] G. della Ventura, P. Bonazzi, R. Oberti, L. Ottolini, Am. Mineral. 87 (2002) 739-744.

[15] N.V. Zubkova, D.Yu. Pushcharovskii, G. Giester, E. Tillmanns, I.V. Pekov, O.D. Krotova, Kristallografiya 49 (2004) 1061-1065.

[16] H. Mueller-Bunz, T. Schleid, Z. Anorg. Allg. Chem. 626 (2000) 845-852.

[17] H. Mueller-Bunz, T. Schleid, Z. Anorg. Allg. Chem. 625 (1999) 1377-1383.

[18] C. Wickleder, I. Hartenbach, P. Lauxmann, T. Schleid, Z. Anorg. Allg. Chem. 628 (2002) 1602-1606.

[19] H. Mueller-Bunz, T. Schleid, Z. Anorg. Allg. Chem. 627 (2001) 218-223.

[20] M.E. Fleet, Y.-M. Pan, Can. Mineral. 33 (1995) 879-884.

[21] V. Maisonneuve, M. le Blanc, Can. Mineral. 36 (1998) 1039-1043.

[22] M. Tang, P. Chiang, Y. Su, Y. Jung, G. Hou, B. Chang, K. Lii, Inorg. Chem. 47 (2008) 8985-8989.

[23] M. Toumi, L. Smiri-Dogguy, A. Bulou, Ann. Chim. 27 (2002) 17-26.

[24] H. Jacobsen, G. Meyer, Z. Kristallogr. 209 (1994) 348-350.
[25] P. Chiang, T. Lin, J. Dai, B. Chang, K. Lii, Inorg. Chem. 46 (2007) 3619-3622.

[26] J.M. Hughes, A.N. Mariano, J.W. Drexler, N. Jahrb, Mineral 1992 (1992) 311-319.

[27] M.C. Schaefer, T. Schleid, Z. Anorg. Allg. Chem. 636 (2010) 2069.

[28] V.P. Balko, V.V. Bakakin, Zh. Strukt. Khim. 16 (1975) 837-842.

[29] O.V. Yakubovich, A.V. Voloshin, Ya.A. Pakhomovskii, M.A. Simonev, Kristallografiya 33 (1988) 605-608.

[30] E.V. Sokolova, Yu.K. Egorov Tismenko, A.V. Voloshin, Ya.A. Pakhomovskii, Dokl. Akad. Nauk SSSR 289 (1986) 1378-1382.

[31] D.C. Noe, J.M. Hughes, A.N. Mariano, J.W. Drexler, A. Kato, Z. Kristallogr. 206 (1993) 233-246.

[32] J. Shen, P.B. Moore, Am. Mineral. 69 (1984) 190-195.

[33] S. Merlino, N. Perchiazzi, Mineral. Petrol. 37 (1987) 25-35.

[34] E.V. Sokolova, G. Ferraris, G. Ivaldi, L.A. Pautov, P.V. Khvorov, N. Jahrb, Minera 2000 (2000) 74-84

[35] J.D. Scott, Can. Mineral. 14 (1976) 515-528.

[36] M. Boiocchi, A. Callegari, L. Ottolini, A. Maras, Am. Mineral. 89 (2004) 1540-1545.

[37] M.C. Schaefer, T. Schleid, Z. Anorg. Allg. Chem. 633 (2007) 1018-1023.

[38] B.V. Merinov, B.A. Maksimov, V.V. Ilyukhin, N.V. Belov, Dokl. Akad. Nauk SSSR 255 (1980) 348-351.

39] M.C. Schaefer, T. Schleid, Z. Anorg. Allg. Chem. 634 (2008) 2074

[40] X. Gong, Y. Lin, Y. Chen, Z. Huang, Y. Huang, Z. Luo, Chem. Mater. 17 (2005) 1135-1138.

[41] C.D. McMillen, J.W. Kolis, J. Cryst. Growth 310 (2008) 2033-2038.

[42] M. Mann, J. Kolis, Acta Crystallogr. C65 (2009) i17-i19.

[43] C.C. Underwood, M. Mann, C.D. McMillen, J.W. Kolis, Inorg. Chem. 50 (2011) 11825-11831.

[44] J.T. Stritzinger, C.D. McMillen, J.W. Kolis, J. Chem. Crystallogr., doi: 10.1007/ s10870-011-0255-8, in press.

[45] M. Mann, J. Kolis, J. Chem. Crystallogr. 40 (2010) 337-342.

[46] C.D. McMillen, J.T. Stritzinger, J.W. Kolis, Inorg. Chem., doi: 10.1021/ ic202318b, in press.

[47] Molecular Structure Corporation \& Rigaku, CrystalClear, Version 1.3, Rigaku Corporation, Tokyo, Japan, and MSC, The Woodlands, TX, USA, 2000.

[48] G.M. Sheldrick, Acta Crystallogr. A64 (2008) 112-122. 